\title{
The role of serum fasting plasma glucose in gestational diabetes screening
}

\author{
İlknur Çöl Madendağ' (D), Mefkure Eraslan Şahin' ${ }^{1}$, Yusuf Madendağ $\breve{g}^{2}$ \\ ${ }^{1}$ Clinics of Gynecology and Obstetrics, Kayseri City Hospital, Kayseri, Turkey \\ ${ }^{2}$ Department of Gynecology and Obstetrics, Faculty of Medicine, Erciyes University, Kayseri, Turkey
}

\begin{abstract}
Objective: We aimed to investigate the performance of fasting plasma glucose (FPG) level, checked between 24 and 28 weeks of gestation, for the diagnosis of gestational diabetes mellitus (GDM) in order to find out whether FPG level would help to identify potential GDM cases or not in pregnancies which do or do not undergo oral glucose tolerance test (OGTT).

Methods: This study was performed retrospectively in a tertiary center by accessing the records of 2950 patients who underwent $75-\mathrm{g}$ OGTT in between 24 and 28 weeks of gestation. GDM diagnosis was established according to the one-step screening test results. In the patients diagnosed with GDM, the most successful threshold value for the diagnosis calculated statistically was determined for FPG. The specificity and sensitivity values were calculated for FPG.

Results: After applying the exclusion criteria, 1736 of 2043 pregnant women were normal and $307(15 \%)$ of them were diagnosed with GDM. The mean age was higher in the pregnant women with GDM than the healthy pregnant women when they were compared according to the demographic characteristics $(28.6 \pm 4.3$ vs. $26.2 \pm 4.1$, $\mathrm{p}<0.001)$. Body mass index was also higher in the pregnant women with GDM compared to the health pregnant women $(26 \pm 2.1$ vs. $\left.24 \pm 3.1 \mathrm{~kg} / \mathrm{m}^{2}, \mathrm{p}<0.001\right)$. Other characteristics were similar in both groups. ROC analysis was performed for FPG and the most significant threshold value was found $88 \mathrm{mg} / \mathrm{dL}$ ( $\mathrm{p}<0.001$, area under curve $0.876,95 \%$ confidence interval $0.850-0.903)$.

Conclusion: When FPG is $>88 \mathrm{mg} / \mathrm{dl}$ in pregnant women who do not want to undergo OGTT, they should be informed in detail about both OGTT and GDM and its potential complications. Thus, the number of GDM cases without diagnosis and its potential complications would decrease.
\end{abstract}

Keywords: Fasting glucose, gestational diabetes, glucose tolerance, pregnancy, screening.

\section{Özet: Gestasyonel diyabet taramasında serum açlık plazma glukozunun yeri}

Amaç: Oral glukoz tolerans testi (OGTT) yaptırmayan veya yaptırılamayan gebeliklerde açlık plazma glukozu (APG) düzeyinin olası gestasyonel diyabet (GDM) olgularının saptanmasında yardımcı olup olamayacağı sorusunu cevaplamak için 24-28. gebelik haftalarında bakılan APG düzeyinin GDM tanısı için nasıl bir performans sergilediğini araştırmayı amaçladık.

Yöntem: $\mathrm{Bu}$ çalışma tersiyer bir merkezde, retrospektif olarak 24-28. gebelik haftaları arasında $75 \mathrm{~g}$ OGTT yaptıran toplam 2950 hastanın kayıtlarına ulaşılarak gerçekleştirildi. Tek basamaklı tarama test sonuçlarına göre GDM tanısı konuldu. GDM tanısı konulan hastalarda APG için istatistiksel olarak hesaplanmış, tanı için en başarılı eşik değer hesaplandı. APG için özgüllük ve duyarlılık değerleri hesaplandı.

Bulgular: Dışlama kriterleri sonrası kalan 2043 gebenin 1736'sı normal iken 307'sine (\% 15) GDM teşhisi konuldu. Sağlıklı gebeler ile GDM'li gebeler arasında demografik özelliklere göre yapılan karşılaştırmada, GDM'li gebelerde ortalama yaş sağlıklı gebelerden yüksek idi (28.6 4 4.3'e karşı 26.2 $\pm 4.1, \mathrm{p}<0.001)$. Vücut kitle indeksi de yine GDM'li gebelerde sağlıklı gebelerden daha yüksek idi $\left(26 \pm 2.1\right.$ 'e karşı $\left.24 \pm 3.1 \mathrm{~kg} / \mathrm{m}^{2}, \mathrm{p}<0.001\right)$. Diğer özellikler her iki grup için benzerdi. APG performansı için ROC analizi yapıldı ve sonrasında en anlamlı eşik değeri $88 \mathrm{mg} / \mathrm{dL}$ olarak tespit edildi ( $\mathrm{p}<0.001$, eğri altında kalan alan $0.876, \% 95$ güven aralı̆̆ 0.850 $0.903)$.

Sonuç: OGTT yaptırmak istemeyen gebelerde, APG $>88 \mathrm{mg} / \mathrm{dl}$ olması durumunda olası GDM için gebe hem OGTT hem de GDM ve olası komplikasyonları hakkında detaylı olarak bilgilendirilmelidir. Böylece tanısı olmayan GDM olguları ve olası komplikasyonlar1 azalacaktır.

Anahtar sözcükler: Açlık glukozu, gestasyonel diyabet, glukoz toleransi, gebelik, tarama.

Correspondence: İlknur Çöl Madendă̆, MD. Clinics of Gynecology and Obstetrics, Kayseri City Hospital, Kayseri, Turkey.

e-mail: ilknurmadendag@gmail.com / Received: December 13, 2019; Accepted: February 17, 2020

Please cite this article as: Çöl Madendağ İ, Eraslan Şahin M, Madendă̆ Y. The role of serum fasting plasma glucose in gestational diabetes screening. Perinatal Journal 2020;28(1):11-16. doi:10.2399/prn.20.0281003 


\section{Introduction}

Gestational diabetes mellitus (GDM) which is the most common endocrinological disorder seen during pregnancy is defined as the carbohydrate intolerance found during second or third trimester and where it is not known clearly if pregnant woman is Type I or Type II diabetes or not. ${ }^{[1]}$ It is associated with prenatal and perinatal complications such as hyperglycemia, preeclampsia, macrosomia, preterm labor, polyhydramnios, traumatic labor, and elevated risk for cesarean section developed during pregnancy. Glucose regulation usually becomes normal in a short time after delivery, but the risk of developing Type II diabetes mellitus increases in these women and their children in the long term. ${ }^{[1]}$ Advanced maternal age, belonging to a certain ethnic group (Hispanic, African, Asian), multiparity, obesity, GDM in previous pregnancy, giving birth to baby over $4000 \mathrm{~g}$ and familial history of diabetes are among the major risk factors. ${ }^{[2]}$

Gestational diabetes screening has still been debated today. There are many recommendations for the screening. These recommendations are serum fasting glucose level, postprandial glucose level, $\mathrm{HbA1C}$ and glucose tolerance tests. Fasting serum glucose threshold value accepted for gestational diabetes diagnosis varies according to the races. ${ }^{[3,4]}$ It is also controversial that performing glucose tolerance test to which pregnant women according to the fasting blood glucose levels would be more significant. Sometimes, tolerance tests cannot be tolerated or are rejected by patients. The number of patients who does not want to undergo the test increases day by day particularly due to the speculations in the social media or the thought that it may harm fetus. ${ }^{[5]}$ In our study, we aimed to investigate the performance of fasting plasma glucose level, checked between 24 and 28 weeks of gestation, for the diagnosis of gestational diabetes mellitus in pregnancies which do or do not undergo oral glucose tolerance test (OGTT).

\section{Methods}

The study was designed retrospectively in the Kayseri City Hospital by using the hospital data bank. The study was carried out by accessing the laboratory results and hospital records of 2950 patients who underwent GDM screening by 75-g OGTT in our clinic between July 2018 and July 2019. The approval of Clinical Researches
Ethics Committee of the Faculty of Medicine, Erciyes University was obtained for the study. Since the ethnic origins in our country have a high risk for diabetes mellitus, all pregnant women admitting to our clinic are recommended 75-g OGTT in accordance with the recommendation of the Practice Guidelines of Turkish Perinatology Society and the tests are carried out for those who accept it. ${ }^{[6]}$ The pregnant women with local ethnic origin (Caucasian race) in between 24 and 28 weeks of gestation and 18-35 years old who admitted to our hospital for routine pregnancy follow-up were included in the study. The patients with fasting plasma glucose above $126 \mathrm{mg} / \mathrm{dl}$ and had previously diagnosed with diagnosis, those with an endocrine disease (Cushing disease, Addison's disease, hypopituitarism, acromegalia etc.) which may affect blood glucose level, or the pregnant women with the history of medication use (cortisol, progesterone) which are known that they may affect blood glucose level were excluded from the study $(n=280$ pregnant women). Also, the patients and immigrants from different races were excluded $(n=595)$. The weeks of gestation were determined according to the last menstrual period. The weeks of gestation for women whose last menstrual period are not known were determined according to the ultrasonographic measurements conducted in the first trimester.

The patients who were screened by one-step 75-g OGTT accepted by IADPSG (International Association of the Diabetes and Pregnancy Study Groups) and ADA (American Diabetes Association) were included in the study. In order to establish diagnosis in one-step screening test, fasting plasma glucose is measured following 12-hour overnight fasting. Then, patient drinks $75 \mathrm{~g}$ glucose and venous blood samples are collected at 1 st and 2 nd hours. $\geq 92 \mathrm{mg} / \mathrm{dl}$ for fasting plasma glucose, $\geq 180 \mathrm{mg} / \mathrm{dl}$ for 1 st hour plasma glucose and $\geq 153 \mathrm{mg} / \mathrm{dl}$ for 2nd hour plasma glucose are accepted as threshold values. ${ }^{[7]}$ GDM diagnosis was established when one or more of these values were higher. The most successful threshold value for the diagnosis was determined by statistically calculating specificity and sensitivity values for fasting plasma glucose (FPG). In this study, 2 simulation screening tests were created. First one was designed to be screening test with single FPG threshold value and the second one to be GDM screening test with two FPG threshold values.

The data were processed and compared by PASW statistics software version 18 (SPSS Inc.; Chicago, IL, 
USA). The descriptive statistics were prepared. The values were presented as mean \pm standard deviation, $\mathrm{n}(\%)$ and median (min-max). The diagnosis performance of FPG value for GDM was analyzed on the basis of ROC (receiver operating characteristic) curve. The sensitivity, specificity, positive and negative likelihood ratios, prevalence, and positive and negative predictive values were determined.

\section{Results}

Of 2950 pregnant women included in the study, 595 were excluded due to different ethnic origin, 32 due to being unable to complete the test, and 280 due to exclusion criteria. While 1736 of remaining 2043 pregnant women were normal, 307 (15\%) of them were diagnosed with GDM (according to IADPSG criteria). The demographic characteristics were compared between the healthy pregnant women and the pregnant women with GDM, and they were presented in the Table $\mathbf{1}$. According to this comparison, mean age was higher in the pregnant women with GDM than the healthy pregnant women $(28.6 \pm 4.3$ vs. $26.2 \pm 4.1, \mathrm{p}<0.001)$. The body mass index was also higher in the pregnant women with GDM than the healthy pregnant women $(26 \pm 2.1$ vs. $\left.24 \pm 3.1 \mathrm{~kg} / \mathrm{m}^{2}, \mathrm{p}<0.001\right)$. Other characteristics were similar for both groups (Table 1).

There were 191 patients with fasting blood glucose $92 \mathrm{mg} / \mathrm{dL}$ and higher $(9.3 \%$ in all pregnant women, $62.2 \%$ in the pregnant women with GDM). There were 179 patients with blood glucose $180 \mathrm{mg} / \mathrm{dL}$ and higher at the 1 st hour of oral glucose tolerance test $(8.7 \%$ in all pregnant women, $58.3 \%$ in the pregnant women with GDM). The number of the patients with blood glucose level $153 \mathrm{mg} / \mathrm{dL}$ and higher at the $2 \mathrm{nd}$ hour of the toler- ance test was 118 (5.7\% in all pregnant women, 38.4\% in the pregnant women with HDM). Of the pregnant women with GDM, single value positivity was observed in $63 \%$ (193), 2-value positivity in $25.9 \%$ (79), and $3-$ value positivity in $10.8 \%$ (33).

The most significant threshold value was found 88 $\mathrm{mg} / \mathrm{dL}$ in the ROC analysis for FPG performance $(\mathrm{p}<0.001$, area under curve $0.876,95 \%$ confidence interval 0.850-0.903). The parameters such as sensitivity and specificity were calculated according to the new threshold value and showed in Table 2. Accordingly, when the best threshold value for FPG was accepted 88 $\mathrm{mg} / \mathrm{dL}$, the false positivity was $6.6 \%$, the specificity was $93.4 \%$ and the sensitivity was $69.7 \%$. Another simulation in this study was to create a screening test with two threshold values according to the FPG level. Three groups were established for that purpose. ${ }^{[4]}$ The first group consisted of 984 (48.2\%) pregnant women with FPG level $<79 \mathrm{mg} / \mathrm{dL}$ and there were $38(12.3 \%)$ patients with GDM in this group. The second group consisted of 868 (42.5\%) pregnant women with FPG level between 79 and $91 \mathrm{mg} / \mathrm{dL}$ and there were 78 (25.4\%) patients with GDM in this group. The third group had a total of 191 (9.3\%) pregnant women with FPG level $92 \mathrm{mg} / \mathrm{dL}$ and higher, and they all had GDM (191/307, 62.2\%). According to this new strategy, if we would establish the cases with APG level 92 $\mathrm{mg} / \mathrm{dL}$ and higher with the diagnosis of GDM directly and perform glucose tolerance test to those between 91 and $79 \mathrm{mg} / \mathrm{dL}, 88 \%$ of the patients with GDM could be diagnosed by conducting OGTT in $42 \%$ of the population. Approximately $58 \%$ of our population would not need OGTT. According to this screening test with two threshold values, specificity was found

Table 1. Comparison of the demographic characteristics between the groups.

\begin{tabular}{lccc} 
& $\begin{array}{c}\text { Healthy pregnant } \\
\text { women (1736) }\end{array}$ & $\begin{array}{c}\text { Pregnant women } \\
\text { with GDM (307) }\end{array}$ & p-value \\
\hline Age & $26.1 \pm 4.1$ & $28.6 \pm 4.3$ & $<0.001$ \\
\hline BMl & $24 \pm 3$ & $26 \pm 2.1$ & $<0.001$ \\
\hline Week of gestation at screening & $26.2 \pm 1.2$ & $25.9 \pm 1.3$ & 0.675 \\
\hline Gravida & $2(1-5)$ & $2(1-6)$ & 0.234 \\
\hline Parity & $1(0-3$ & $1(0-3)$ & 0.454 \\
\hline
\end{tabular}

BMI: body mass index; GDM: gestational diabetes mellitus. The values were presented as mean \pm standard deviation or median (min-max). $p<0.05$ was considered statistically significant. 
Table 2. The performance when the serum fasting glucose threshold value is calculated $88 \mathrm{mg} / \mathrm{dL}$.

\begin{tabular}{lcc} 
Statistics & Results & $95 \% \mathbf{C l}$ \\
\hline Sensitivity & $69.71 \%$ & $64.23-74.8 \%$ \\
\hline Specificity & $93.43 \%$ & $92.16-94.55 \%$ \\
\hline Positive likelihood ratio & 10.62 & $8.76-12.87$ \\
\hline Negative likelihood ratio & 0.32 & $0.27-0.38$ \\
\hline Prevalence & $15.03 \%$ & $13.5-16.65 \%$ \\
\hline Positive predictive value & $65.24 \%$ & $60.77-69.46 \%$ \\
\hline Negative predictive value & $94.58 \%$ & $93.64-95.39 \%$ \\
\hline Accuracy & $9.87 \%$ & $88.48-91.14 \%$ \\
\hline
\end{tabular}

ROC analysis was conducted for the performance of serum fasting glucose level, and then $88 \mathrm{mg} / \mathrm{dL}$ was considered to be the most significant threshold value ( $\mathrm{p}<0.001$, area under curve $0.876,95 \%$ confidence interval $0.850-0.903$ ). For the disease diagnosis, the results of $75-g$ oral glucose tolerance test, which is the reference test, was used.

$100 \%$ and sensitivity $87.6 \%$. The calculations of other threshold values are given in Table 3 .

\section{Discussion}

In our study, we investigated the diagnosis convenience for GDM which is one of the most common medical issues encountered during pregnancy and may lead to many poor health outcomes by affecting both mother and baby in short- and long-term. GDM screening and diagnosis are still controversial. In our study, we investigated the diagnosis performance of FPG levels between 24 and 28 weeks of gestation. There are few studies in the literature investigating the diagnosis performance of FPG. We developed the methods of our study and improved the power of the study by taking the limitations in these studies into consideration (advanced maternal age, different ethnic groups, risky pregnancies and obese pregnant women in the study groups). Firstly, we designed the study population to be between 18 and 35 years old. Unlike similar studies, we excluded different ethnic origins from our study, and included only local individuals. Also, we included pregnant women whose body mass index was between 20 and $30 \mathrm{~kg} / \mathrm{m}^{2}$ in our study in order to increase the reliability of our study.

The first strategy we considered as a hypothesis in our study was to conduct screening by using a single threshold value which has the highest performance for GDM diagnosis, and the FPG level with the highest validity was $88 \mathrm{mg} / \mathrm{dL}$. When assuming that this value is considered as threshold value in the screening, we will be able to establish GDM diagnosis to our population with an acceptable specificity rate of $93.4 \%$ and sensitivity rate of $69.7 \%$, and the need for conducting tolerance test will be eliminated for a great part (83\%) of the pregnant women. However, a significant part $(30 \%)$ of the pregnant women with GDM would be missed in this assumption.

Table 3. The performance of serum fasting glucose at different threshold values.

\begin{tabular}{|c|c|c|c|c|c|c|}
\hline & 92 & 88 & 79 & 75 & 72 & 70 \\
\hline $\begin{array}{l}\text { Number of pregnant women } \\
\text { above threshold }\end{array}$ & $\begin{array}{l}191 / 2043 \\
(9.3 \%)\end{array}$ & $\begin{array}{c}328 / 2043 \\
(16.1 \%)\end{array}$ & $\begin{array}{c}1059 / 2043 \\
(51.8 \%)\end{array}$ & $\begin{array}{c}1475 / 2043 \\
(72.2 \%)\end{array}$ & $\begin{array}{c}1721 / 2043 \\
(84.2 \%)\end{array}$ & $\begin{array}{c}1846 / 2043 \\
(90.4 \%)\end{array}$ \\
\hline $\begin{array}{l}\text { Number of pregnant women } \\
\text { that do not require OGTT }\end{array}$ & $\begin{array}{c}1852 / 2043 \\
(90.7 \%)\end{array}$ & $\begin{array}{c}1715 / 2043 \\
(83.9 \%)\end{array}$ & $\begin{array}{c}984 / 2043 \\
(48.2 \%)\end{array}$ & $\begin{array}{c}568 / 2043 \\
(27.8 \%) \\
\end{array}$ & $\begin{array}{c}322 / 2043 \\
(15.8 \%) \\
\end{array}$ & $\begin{array}{c}197 / 2043 \\
(9.6 \%)\end{array}$ \\
\hline $\begin{array}{l}\text { Number of GDM cases missed } \\
\text { by the test }\end{array}$ & $\begin{array}{l}116 / 307 \\
(37.7 \%)\end{array}$ & $\begin{array}{l}93 / 307 \\
(30.2 \%)\end{array}$ & $\begin{array}{l}38 / 307 \\
(12.3 \%)\end{array}$ & $\begin{array}{l}21 / 307 \\
(6.8 \%)\end{array}$ & $\begin{array}{l}12 / 307 \\
(3.9 \%)\end{array}$ & $\begin{array}{l}4 / 307 \\
(1.3 \%)\end{array}$ \\
\hline Sensitivity & $\begin{array}{l}191 / 307 \\
(62.2 \%)\end{array}$ & $\begin{array}{l}214 / 307 \\
(69.7 \%)\end{array}$ & $\begin{array}{l}269 / 307 \\
(87.6 \%)\end{array}$ & $\begin{array}{l}286 / 307 \\
(93.2 \%)\end{array}$ & $\begin{array}{l}295 / 307 \\
(96.1 \%)\end{array}$ & $\begin{array}{l}303 / 307 \\
(98.7 \%)\end{array}$ \\
\hline Specificity & $\begin{array}{c}1736 / 1736 \\
(100 \%)\end{array}$ & $\begin{array}{c}1622 / 1736 \\
(93.4 \%)\end{array}$ & $\begin{array}{c}946 / 1736 \\
(54.5 \%)\end{array}$ & $\begin{array}{c}547 / 1736 \\
(31.5 \%)\end{array}$ & $\begin{array}{c}310 / 1736 \\
(17.9 \%)\end{array}$ & $\begin{array}{c}193 / 1736 \\
(11.1 \%)\end{array}$ \\
\hline
\end{tabular}

GDM: gestational diabetes mellitus; OGTT: oral glucose tolerance test. The values were presented as $\mathrm{n}(\%)$. The descriptive statistics were done. 
Another strategy is to separate pregnant women to 3 groups between 24 and 28 weeks of gestation according to their FPG levels. ${ }^{[4,8-10]}$ In accordance with the reports of similar studies, pregnant women with FPG level 92 $\mathrm{mg} / \mathrm{dL}$ and higher are already diagnosed with GDM according to the reference test and glucose tolerance test is not required. The pregnant women with FPG levels below $79 \mathrm{mg} / \mathrm{dL}$ which are almost half of the population (48.2\%) do not undergo tolerance test. The purpose here is to determine risk group, and recommend glucose tolerance test to those with FPG level between 79 and 92 $\mathrm{mg} / \mathrm{dL}$. When we evaluate the results of our study with this scenario, glucose tolerance test is not required in a great part $(58 \%)$ of all pregnant women and $88 \%$ of the patients will be diagnosed who are established with GDM diagnosis according to the reference test by conducting OGTT in $44 \%$ of them. In this way, the sensitivity was $88 \%$ and the specificity was $100 \%$ in this strategy. We found that a similar study in the literature reported consistent results with our study. Zhu et al. reported the sensitivity $87 \%$ in their study performed with 24,854 patients in China in 2013. ${ }^{[9]}$ In a similar study which has $100 \%$ specificity but different sensitivity compared to our study, Agarwal et al. used this strategy on 10,283 patients in 2010 and reached a sensitivity of $95.4 \% .{ }^{[10]}$ In a similar study conducted with 2298 cases, Ryser Rüetschi et al. reported the sensitivity rate $78.5 \% .{ }^{[4]}$ When this strategy was compared with the data of HAPO (Hyperglycemia and Adverse Pregnancy Outcome) study, it was reported that $57 \%$ of the patients would not need OGTT with a sensitivity of $84.1 \% \cdot{ }^{[8]}$ While these different results are reported as the study limitations, secondary factors such as different ethnic groups, pregnancies at advanced ages, risky pregnancies and obesity may lead to different rates of prevalence, sensitivity and specificity.

A good screening test is expected to be cheap and easy to perform in a short time without requiring detailed preparations, and its validity (total of sensitivity and specificity), the method used in other words, should be real, solid and have a high rate of identifying patients. The ideal one is the high sensitivity with $95 \%$ specificity, which means $5 \%$ false positivity rate. If we consider $88 \mathrm{mg} / \mathrm{dL}$ as the threshold FPG value, the rates accepted in many screening tests can be achieved with $93.4 \%$ specificity and $69.7 \%$ sensitivity. It is similar in 50 -g glucose screening test. ${ }^{[11]}$ When $140 \mathrm{mg} / \mathrm{dL}$ is accepted as the threshold value according to ADA criteria, the speci- ficity is $84 \%$ and the sensitivity is $88 \%$; but if the threshold value is considered to be $130 \mathrm{mg} / \mathrm{dL}$ according to NDDG (National Diabetes Data Group) criteria, the specificity is $88 \%$ and the sensitivity is $66 \%{ }^{[11]}$ It can be said that a better performance than 50 -g glucose screening test is obtained in two-threshold screening strategy with $100 \%$ specificity and $87.6 \%$ sensitivity.

This study has a few weak points. Conducting the study retrospectively, in a single center and with low number of pregnant women are among them. The number of pregnant women included in the study decreased due to the exclusion criteria. However, the exclusion criteria increase the strength of the study. Another significant aspect of the study is that we conducted it with the data of our country.

\section{Conclusion}

According to the results of our study, a GDM screening test using FPG threshold value $88 \mathrm{mg} / \mathrm{dL}$ alone missed $30 \%$ of real GDM cases, and exhibited a poor performance with $93.4 \%$ specificity and $69.7 \%$ sensitivity. Another GDM screening test designed in the study had two threshold values. This screening test designed by using 92 and $79 \mathrm{mg} / \mathrm{dL}$ FPG values missed $12 \%$ of the cases, and exhibited a good performance with $100 \%$ specificity and $87.6 \%$ sensitivity. In the cases who could not undergo or did not want to undergo OGTT, reevaluating the cases with FPG values would provide an opportunity to inform the cases in detail about potential gestational diabetes and to perform diagnosis test. Thus, the number of non-diagnosed GDM cases and potential complications would decrease.

Conflicts of Interest: No conflicts declared.

\section{References}

1. American Diabetes Association. 2. Classification and diagnosis of diabetes: standards of medical care in diabetes-2018. Diabetes Care 2018;41:S13-27.

2. Hod M, Kapur A, Sacks DA, Hadar E, Agarwal M, Di Renzo GC, et al. The International Federation of Gynecology and Obstetrics (FIGO) initiative on gestational diabetes mellitus: a pragmatic guide for diagnosis, management, and care. Int J Gynaecol Obst 2015;131 Suppl 3:S173-211.

3. Sacks DA, Hadden DR, Maresh M, Deerochanawong C, Dyer AR, Metzger BE, et al.; HAPO Study Cooperative Research Group. Frequency of gestational diabetes mellitus at collaborating centers based on IADPSG consensus panel-recom- 
mended criteria: the Hyperglycemia and Adverse Pregnancy Outcome (HAPO) study. Diabetes Care 2012;35:526-8.

4. Ryser Rüetschi J, Jornayvaz FR, Rivest R, Huhn EA, Irion O, Boulvain $M$. Fasting glycaemia to simplify screening for gestational diabetes. BJOG 2016;123:2219-22.

5. Başbuğ A, Sönmez CI, Kaya AE, Yıldırım E. An important problem in gestational diabetes scan: why do pregnant women refuse to have oral glucose tolerance test? [Article in Turkish] Konuralp Tip Dergisi 2018;10:144-8.

6. Şen C, Yayla M, Api O, Yapar Eyi EG, Ülkümen BA. Diabetes in pregnancy: diagnosis and treatment. Practice Guidelines of Turkish Perinatology Society. Perinatal Journal 2016;24:110 27.

7. International Association of Diabetes and Pregnancy Study Groups Consensus Panel; Metzger BE, Gabbe SG, Persson B, Buchanan TA, Catalano PA, Damm P, et al. International association of diabetes and pregnancy study groups recom- mendations on the diagnosis and classification of hyperglycemia in pregnancy. Diabetes Care 2010;33:676-82.

8. Agarwal MM, Weigl B, Hod M. Gestational diabetes screening: the low-cost algorithm. Int J Gynaecol Obstet 2011;115 Suppl 1:S30-3.

9. Zhu WW, Fan L, Yang HX, Kong LY, Su SP, Wang Z, et al. Fasting plasma glucose at 24-28 weeks to screen for gestational diabetes mellitus: new evidence from China. Diabetes Care 2013;36:2038-40.

10. Agarwal MM, Dhatt GS, Shah SM. Gestational diabetes mellitus: simplifying the International Association of Diabetes And Pregnancy diagnostic algorithm using fasting plasma glucose. Diabetes Care 2010;33:2018-20.

11. Donovan L, Hartling L, Muise M, Guthrie A, Vandermeer B, Dryden DM. Screening tests for gestational diabetes: a systematic review for the US Preventive Services Task Force. Ann Intern Med 2013;159:115-22.

Bu makalenin kullanım izni Creative Commons Attribution-NoCommercial-NoDerivs 3.0 Unported (CC BY-NC-ND3.0) lisansı aracılığıyla bedelsiz sunulmaktadır. / This work is licensed under the Creative Commons Attribution-NonCommercial-NoDerivs 3.0 Unported (CC BY-NC-ND3.0) License. To view a copy of this license, visit http://creativecommons.org/licenses/by-nc-nd/3.0/ or send a letter to Creative Commons, PO Box 1866, Mountain View, CA 94042, USA. 